\title{
CONSTRUINDO ALTERIDADES: A TRAJETÓRIA DE VIDA DE UM JOVEM IMIGRANTE NO BRASIL (CURITIBA, SEGUNDA METADE DO SÉCULO XIX)
}

\author{
Drawing the otherness: \\ The life of a young immigrant in Brazil \\ (Curitiba, late 19th century)
}

Sergio Odilon Nadalin*

Fugindo das consequências políticas das revoluções de 1848 , os Strobel "deixaram a pequena cidade de Glauchau, na Saxônia, em 1854, com um grupo de mais de trinta pessoas. Sete homens que viajavam sozinhos (quatro tecelóes com 17 , 21, 24 e 39 anos, dois sapateiros de 21 anos, um cordoeiro de 37 anos e um tipógrafo de 29 anos); dois casais sem filhos (um advogado de 36 anos e a esposa de 32, um homem de 32 anos de profissão desconhecida com a esposa, da mesma idade). Dos casais com filhos, além dos Strobel (Christian com 35 anos, a esposa Christine com 28 anos, os filhos Emilie Bertha, Gustav Hermann e Emil Robert, com respectivamente 7, 5 e 1 ano) partiu, também a família de um médico de 36 anos, com mulher (39 anos) e quatro filhos entre 10 e 3 anos, a familia de um moldador de 25 anos, com mulher (22 anos) e uma filha de 1 ano e meio; a família de um industrial de 43 anos e sua esposa de 39 anos, formada por 10 pessoas, entre elas algumas de sobrenomes diferentes, mas, possivelmente, parentes. No grupo, todos eram protestantes" $"$.

\footnotetext{
" Doutor em História e Geografia das Populações (EHESS), Professor Associado do Departamento de História da Universidade Federal do Paraná e Pesquisador do CNPq.

1 MACHADO, C. S. De uma família imigrante: sociabilidade e laços de parentesco. Curitiba: Aos Quatro Ventos, 1998, p. 14. A autora explica que utiliza o termo "industrial" tal como aparece na lista de passageiros do Navio Florentin, desembarcados em 11 de novembro de 1854 no porto de São Francisco. A relação de passageiros do "Florentin", publicada por BÖBEL, M. T.; THIAGO, R. S. Joinville - os pioneiros: depoimentos e histórias, v. 1, 2001, p. 177, listava 213 imigrantes oriundos principalmente do Hanover, da Saxônia, da Prússia e da Suíça.
} 


\title{
RESUMO
}

$\mathrm{O}$ artigo objetiva, tendo como ponto de partida a releitura das memórias de Gustav Hermann Strobel (1851-1933), discutir o conceito e a constituição de etnicidades teuto-brasileiras (Deutschbrasilianertum), considerando a construção de um grupo social de origem germânica e evangélica-luterana em Curitiba durante a segunda metade do século XIX e primeira metade do século XX. Também pretende discutir como, independente do isolamento geográfico, a situação de contato cotidiano com "o outro" num meio urbano constitui igualmente fator de etnicidade. Está implícita na conclusão a convocatória para que se desenvolvam pesquisas comparativas fundamentadas em análises locais diferenciadas social e historicamente.

Palavras-chave: imigração; grupos étnicos; memória; urbanização.

\begin{abstract}
The purpose of this article based on a re-reading of Gustav Hermann Strobel's (1851-1933) memoirs is to discuss the concept and formation of German-Brazilian (Deutschbrasilianertum) ethnicities, taking into account the construction of a social group of German and LutheranEvangelic origin, in Curitiba, during the second half of the $19^{\text {th }}$ century and first half of the $20^{\text {th }}$. It also aims at discussing how, regardless of geographic isolation, daily contact with "the other" in the rural environment also constitutes an ethnicity factor. Implied in the conclusion is an invitation to the development of further comparative research based on social and historically different local analyses.
\end{abstract}

Keywords: immigration; ethnic groups; memory; urbanization.

Gustav Hermann Strobel, o segundo filho de Christine Friederika e Christian August, registrou num relato a sua vida e a de sua família "para que as gerações futuras saibam [soubessem] de onde procederam seus antepassados e por quais dificuldades tiveram que passar, até que chegassem a um padrão de vida relativamente bom e decente"2. Um de seus descendentes atendeu a esse desejo, recuperando e traduzindo o manuscrito para o português, e o Instituto Histórico, Geográfico e Etnográfico Paranaense ampliou, com sua publicação, o alcance dos objetivos do memorialista.

2 STROBEL, G. H. Relatos de um pioneiro da imigração alemã. Curitiba: IHGEP, 1987, p. 3. 
Ficou, assim, disponibilizado aos pesquisadores interessados na imigração alemã um rico documento que servirá, nestas páginas, para recolocar algumas questões relacionadas aos processos de inserção dos imigrantes na sociedade receptora ${ }^{3}$.

"O que eu aqui relato" - anuncia nossa testemunha - "é absolutamente a expressão da verdade, com exceção talvez de coisas que foram contadas a meus pais ou a mim, as quais só reproduzo para que o leitor tenha uma ideia dos usos e modos de vida desta época". Não obstante, trataremos a fonte como tal, com a necessária atitude crítica do historiador: seus pais já haviam falecido quando Gustav Hermann ${ }^{4}$, com mais de sessenta anos ${ }^{5}$, lançou-se nesse empreendimento. Articulou "fatos" do passado da família com impressões, opiniões e críticas que lançam luz, principalmente, ao processo de etnização sofrido pelo depoente no curso de sua vida, acompanhando de perto, ao que parece, histórias semelhantes percorridas por outros membros do grupo imigrante da mesma geração pioneira.

De acordo com a narração, os membros da família Strobel que vieram ao Brasil fugiram da Europa por motivos políticos - o que está de acordo com a historiografia ${ }^{6}$ - e não constituiriam, pois, emigrantes típicos. Relativizando esta ênfase da minha fonte, é possível, também, entender a emigração do casal e outras pessoas de Glauchau, na Saxônia, como resultado da pobreza reinante na Alemanha anterior à Revolução Industrial e da incapacidade de os artesãos se ocuparem nos limitados mercados locais? De uma forma ou de outra, o alegado roubo de seu pequeno capital logo

3 Foi traduzido para o português por Egon F. Strobel e publicado em 1987 como Número 27 da "Estante Paranista", recebendo o título Relatos de um pioneiro da imigração alemã. Essas memórias estão incompletas e o tradutor observa não conhecer os motivos dessa lacuna em nota final (p. 141). A partir de outra nota, é possível depreender que Gustav teria uma veia literária. Não só escreveu suas memórias como teria escrito um segundo livro [sic], "este de conteúdo mais político e filosófico, do qual não se tem mais notícias, seja do original ou de cópias" (p. 141).

4 Christine Friederika Herold Strobel faleceu em 23 de junho de 1898 e Christian August Strobel em 11 de janeiro de 1900.

5 Não se sabe exatamente quando ou em que período de sua vida o seu texto foi criado. No início do século XX, sem dúvida, e a data mais recente mencionada nas suas memórias refere-se a um comentário sobre a liberação de verbas em 1912 para a reparação da Estrada da Graciosa (STROBEL, 1987, p. 115).

6 Eram os "1848 er Kinder", os filhos de 1848. MAGALHÃES, 1998, p. 26. Ver também, WILLEMS, 1980, p. 36; HOBSBAWM, 2004, p. 280.

7 SINGER. Desenvolvimento econômico e evolução urbana: análise da evolução econômica de São Paulo, Blumenau, Porto Alegre, Belo Horizonte e Recife. São Paulo: Editora Nacional; Editora USP, 1968, p. 87. 
antes da viagem ${ }^{8}$ nivelou-os aos $80 \%$ de alemães da primeira grande leva emigratória de 1845 a 1854 , que fugiam da fome ou das pressões pela terra9 num país econômica e politicamente atrasado ${ }^{10}$.

O casal e seus três filhos nascidos na Alemanha - Emilie Bertha (01.09.1846), Gustav Hermann (01.07.1851) e Emil Robert (1853) - foram, de certa maneira, pioneiros no processo de migração que conduziu centenas de "colonos" de origem germânica da colônia Dona Francisca ${ }^{11}$ e de outras partes da então Província de Santa Catarina a Curitiba. Primeiramente o marido, que veio tentar a sorte no planalto curitibano, chegando no início de 1855; alguns meses depois, subiram a serra Christine, grávida, e os filhos.

Sem recursos e desconhecendo a língua dos nativos, eles dependeram em grande parte do que podiam produzir; mas, sem dúvida, também da "boa estrela" do imigrante ${ }^{12}$. Gustav Hermann deixou implícito que seus pais nunca se desencorajaram; recorriam a pequenos serviços e viviam assim do que conseguia ganhar o marido desenvolvendo diversos tipos de trabalho. Não eram, essencialmente, serviços de carpintaria: para citar um exemplo, Christian trabalhou durante bom período abrindo valetas e a família vendia na cidade excedentes produzidos nas hortas das diversas casas que alugaram sucessivamente, até comprarem a sua própria; ganhavam igualmente um pouco de dinheiro alojando imigrantes que estavam de passagem ou se instalavam na região, ao sul de Curitiba e no caminho que unia o planalto às colônias de Santa Catarina.

Durante essa fase, o estabelecimento dos Strobel na capital paranaense é sinalizado pela retomada do crescimento da família, tendo-lhes nascido mais três filhos: Maria (08.07.1855), Anna Luiza (07.12.1858) e Fani (ou Fanni) (17.11.1861) ${ }^{13}$. Apesar de luteranos, a ausência ainda de

8 STROBEL, G. H. Op. cit., 1987, p. 31.

9 HOBSBAWM, E. J. A era do capital: 1848-1875. 10. ed. Rio de Janeiro: Paz e Terra, 2004, p. 280-281 (a referência inclui, além da Alemanha, a Irlanda).

10 Cacilda da Silva Machado também relativizou a explicação de Gustav Hermann no que concerne aos motivos da emigração. Na conclusão de sua dissertação, a autora mostra como procurou, nesse sentido, "enfatizar mais as realizações pessoais de Christian Strobel, concretizadas somente porque decidiu-se pela imigração. Neste procedimento, o impulso de fuga de uma proletarização iminente revelouse uma via de explicação muito mais esclarecedora para a compreensão do fenômeno da Grande Migração no século XIX" (MACHADO, C S. Op. cit., 1998, p. 112).

11 Depois Joinville.

12 MACHADO, C. S. Op. cit., 1998, p. 9 et seq.

13 Em nenhum momento de seu texto Gustav menciona o nome das irmãs nascidas no Paraná. As informações acima foram obtidas dos registros de batismos da Matriz de São José dos Pinhais. 
uma assistência evangélica levou-os a batizar suas filhas na Igreja Católica, com padrinhos escolhidos entre seus amigos brasileiros. Gustav Hermann relatou a dificuldade em batizar Anna Luiza:

A igreja mais próxima ficava em São José dos Pinhais e para chegar lá levavam-se seis horas de caminhada. Era difícil para meus pais se ausentarem por tanto tempo. Um vizinho nosso, senhor Rocha, prontificou-se a levar a criança até São José [dos Pinhais] para batizá-la, e também assumir o papel de padrinho. Meus pais aceitaram de bom grado esta oferta e no dia marcado o casal, acompanhado por uma escrava que servia como ama, chegou em montarias para que levassem a criança para o batismo ${ }^{14}$.

Foi neste contexto de um novo mundo do trabalho e do processo de inserção numa sociedade distinta daquela da qual eram originários que nasceram os três últimos filhos do casal. A linhagem constituía-se, assim, imersa nos contatos de aculturação ${ }^{15}$ e de socialização que incluíam relações comerciais e de trabalho no mercado oferecido pela cidade. Essas relações desenvolviam-se pouco a pouco com a demanda dos empregadores de origem brasileira, enquanto seus serviços especializados eram cada vez mais solicitados por mestres de obra alemães que marcaram a renovação urbana de Curitiba até os anos de 1890-1899 ${ }^{16}$.

14 STROBEL, G. H. Op. cit., 1987, p. 62. Também Fani, a caçula, foi apadrinhada por um casal de vizinhos, Custódio da Cruz e esposa. "Ele era o mais novo dos irmãos Cruz, e pessoa de muito bom trato. Como presente de batizado, ofereceram-nos um novilho e quando foram trabalhar em sua roça permitiram-nos, durante sua ausência, a ordenha de suas vacas e o aproveitamento do leite obtido" (p. 70).

15 Acreditamos que ainda é possível acompanhar Nathan Wachtel quando, em 1974, sugeria que "o termo desejaria designar todos os fenômenos de interação que resultam do contato de duas culturas", apesar de ter ciência das ambiguidades do conceito, nascido de uma situação "colonial" (WACHTEL, N. A aculturação. In: Le GOFF, J.; NORA, P. História: novos problemas. 3. ed. Rio de Janeiro: Francisco Alves, 1988, p. 113-114). Para Schnaper, a noção de aculturação permite a análise da "integração dos imigrados como um processo dinâmico de reinterpretação, de negociação e de ajustes culturais, dos quais os imigrados são os atores" (POUTIGNAT, P.; STREIFF-FENART, J. Teorias da etnicidade: seguido de grupos étnicos e suas fronteiras, de Fredrik Barth. São Paulo: Fundação Editora da UNESP, 1998, p. 175). Finalmente, de acordo com Fredrik Barth, o conceito exprime a interação que permite a construção e transformação da identidade étnica (LAPIERRE, 1998, p. 11).

16 A esse respeito, ver o item "Atuação dos empreiteiros alemães em Curitiba", na dissertação de Denise Eurich Colatusso (2004, p. 48-57). 
O documento em referência permite inferir o choque do imigrante ao se deparar com o novo meio, quando desembarcaram no porto de São Francisco (do Sul), no litoral norte de Santa Catarina, e tiveram contato com a mata virgem. Ao subirem o Rio Cachoeira na direção da colônia,

[...] a decepção era visível nos rostos de cada um, pois a vegetação fechada que víamos nas margens era um tanto assustadora. Água adentro avançavam as plantas aquáticas, e ao fundo o mato virgem era aterrador. [...] Pensar em viver nestas paragens, parecia-nos um tanto apavorante ${ }^{17}$.

Chegando ao lugar previsto, depararam-se com precárias instalações. Para que pudessem sobreviver, era preciso preparar a terra e plantar, mas, antes, derrubar a floresta. Além de tudo, foram mal recebidos e, assim, a primeira reação do grupo que desembarcara teria sido a de voltar ${ }^{18}$. Dada essa evidente impossibilidade, os colonos trataram de resolver os problemas da maneira como podiam, confrontando as agruras de um meio hostil com o trabalho duro da derrubada da mata, ao que parece enfrentando a falta de comida, insetos, bichos-de-pé, aranhas, serpentes e outros animais igualmente assustadores ${ }^{19}$. Essas memórias fortalecem os relatos sobre o pioneirismo do "imigrante alemão", que permeiam as crônicas sobre trajetórias bem-sucedidas ${ }^{20}$. Por aquele motivo, "muitos como nós preferiram se mudar para o [...] Paraná, onde o clima era também mais favorável para os colonos alemães" ${ }^{\prime 2}$, e onde, naturalmente, havia uma cidade já constituída a explorar.

De qualquer modo, em Curitiba o início também seria difícil. Ao chegar,

[...] meu pai percorreu em seguida todas as ruas da cidade à procura de trabalho. Onde via ou ouvia ruí-

17 STROBEL, G. H. Op. cit., 1987, p. 29.

18 Ibid., p. 30.

19 Ibid., p. 30-34.

20 SEYFERT, G. Identidade étnica, assimilação e cidadania: a imigração alemã e o Estado Brasileiro. In: ENCONTRO ANUAL DA ANPOCS, XVII. Caxambu, MG, 22-25 outubro de 1993, p. 4.

21 SEYFERT, G. Identidade étnica, assimilação e cidadania..., 1993, p. 35. 
dos de serras ou cepilhos indagava por trabalho, mas sem sucesso. Também no edifício da Assembléia, que estava sendo construído na época, perguntou por trabalho. Mas os operários e carpinteiros que eram todos mulatos não conseguiram entender sua comunicação através de gestos. Em resposta meu pai obteve apenas risos. Desanimado, seguiu adiante, achando cada vez mais injusto animar pessoas com falsas promessas, para virem a estas paragens, sem prestar-lhes a minima assistência $[\ldots]^{22}$.

Ainda que no caminho de Dona Francisca para Curitiba já tivessem se deparado com "caboclos" 23 - que consideraram "gente muito hospitaleira" -, foi no planalto que tiveram de romper não só as barreiras da língua, mas também se relacionar com uma população autóctone singular, descendentes de colonos mesclados aos indígenas e africanos. Não era só uma população "diferente": ainda em relação aos caboclos, o memorialista opina, quase meio século depois de os fatos terem acontecido, que estes "os aceitavam de bom grado sem exigir algo em troca. Sentiam-se mesmo honrados quando um branco (grifo meu) entrava em suas casas" 24 .

Daquele momento em diante, o cotidiano da família estaria marcado pela sua inserção numa sociedade cuja estrutura social patriarcal e escravista era evidente: "nos primeiros anos de nossa estada no Paraná, vivemos sempre neste meio, e nos dávamos muito bem com os nativos, respeitando-os naturalmente, e nunca ofendendo nenhum deles" ${ }^{\prime 25}$. Por outro lado, os Strobel parecem não ter se impressionado com os escravos que encontraram em Curitiba - pelo menos, se dermos crédito a nossa fonte. De qualquer forma, ao comentar sobre a amizade revelada por Pedro Machado, abastado dono

22 SEYFERT, G. Identidade étnica, assimilação e cidadania..., 1993, p. 40. De fato, as reclamações eram coerentes com a desorganização do desenvolvimento dos projetos de colonização, embora Dona Francisca constituísse um empreendimento particular. A falta de recursos públicos para os assentamentos "estava longe da perfeição estabelecida na legislação e nos planos traçados no âmbito do Ministério da Agricultura. O cotidiano das primeiras décadas da maioria das colônias foi marcado pela insegurança gerada por problemas fundiários e pelas deficiências dos serviços públicos essenciais" (SEYFERT, 1993, p. 3).

23 STROBEL, G. H. Op. cit., 1987, p. 39.

24 Id.

25 Id. 
de grandes extensões de terras e proprietário de gado, muares e quantidade de escravos, nossa testemunha relata, até friamente:

O fato de possuir escravos numerosos era um sinal de riqueza. Estes escravos eram negociados igual ao gado. Um escravo masculino, na faixa de vinte a trinta e cinco anos, custava geralmente mil mil-réis (um conto de réis), o equivalente a dois mil marcos. Os de idade menor, os mais velhos, e os do sexo feminino, eram negociados por preços inferiores. Os que possuíam escravos fortes e saudáveis, lucravam boas somas com a reprodução destes. Os escravos eram apenas alimentados e vestidos pelos seus amos, e apenas aos domingos e feriados podiam trabalhar para ganhar algum dinheiro próprio ${ }^{26}$.

Ademais, tiveram de se acostumar com outras novidades, como "a principal refeição brasileira: feijão preto, farinha de milho ou mandioca e charque. De vez em quando também tinha canjica", também feita a partir do milho, que as crianças aprenderam a apreciar, "principalmente se preparada com leite e açúcar"; apesar do estranhamento inicial, parece que, de modo igual, logo se habituaram à infusão do mate e à maneira muito especial de ingeri-lo. Mesmo o eventual trabalho de carpintaria que Christian conseguia nos primeiros meses fugia dos padrões aos quais estava acostumado, pois a madeira não era fornecida em tábuas serradas: eram pranchões brutos aplainados a machado e que exigiam acabamento a cepilho ${ }^{27}$.

Mesmo com todas essas dificuldades, o que a família Strobel sentiu, em Curitiba, parece não ter sido hostilidade - tal sensação teria passado quando deixaram a Colônia D. Francisca. Assim sendo, não cabe à nova situação deles a observação de Hobsbawm a respeito do imigrante típico, que seria "amontoado com seus iguais em um lugar estranho que o havia recebido de forma fria [... voltando-se] naturalmente para o único agrupamento humano que lhe era familiar e que poderia ajudá-lo, a companhia dos seus compatriotas" ${ }^{28}$. Mesmo porque muitos dos quase duzentos

26 STROBEL, G. H. Op. cit., 1987, p. 52-53. Sobre o padrinho da irmã Fani, menciona que "a família Rocha também era bem abastada. Possuíam grande extensão de terras e muitos escravos" (p. 63).

27 STROBEL, G. H. Op. cit., 1987, p. 41.

28 HOBSBAWM, E. J. Op. cit., 2004, p. 277. “A primeira geração de imigrantes, por mais zelosa que fosse ao tentar aprender as técnicas da nova vida, terminava por viver num gueto autoimposto, 
estrangeiros que viviam na capital do Paraná - alguns, alemães oriundos da colônia de Rio Negro, na mesma Província; outros, que continuavam a chegar de Santa Catarina -, não podiam ser considerados, naquele momento, "compatriotas", como eram os seus companheiros da Saxônia. Com efeito, os primeiros, porque originários do Moselle e relativamente integrados à sociedade curitibana desde os anos de 1830; os outros, porque eram oriundos de lugares muito distintos, tais como a Pomerânia e outras regiões da Prússia, do Schleswig-Holstein, do Hanover, de Schaffhausen (no norte da Suíça) e assim por diante. Além de tudo, esses "remigrantes" estavam em grande maioria se instalando no extremo oposto da cidade, no norte, em lotes de terreno especialmente destinados a eles pelas autoridades provinciais.

$\mathrm{O}$ que se configura, portanto, para os Strobel e para muitos que subiam a serra naquele momento fixando-se no planalto, é que, pelo menos nos 10 anos que se sucederam ao início da remigração, parece que não se havia ainda manifestado nenhuma mobilização coletiva direcionada à etnicidade; ou seja, a uma "pertença" étnica ${ }^{29}$. Sem dúvida, o "nós" e o "outro" sempre foram evidentes nas relações estabelecidas com os nativos e-apesar de essa questão não ter afetado diretamente a família, como vimos - isso ficara evidente quando os luteranos tiveram dificuldades em enterrar seus mortos no cemitério público, terra consagrada pela Igreja católica: a Câmara Municipal veio em socorro dos imigrantes, concedendo-lhes terra para a edificação de um cemitério.

Assim, a despeito das diferenças culturais, dos problemas e eventuais hostilidades, até então parecia não se configurar, entre os imigrantes, a

apoiando-se nas velhas tradições, nos seus semelhantes e nas memórias do antigo país, que tinham abandonado tão prontamente" (Idem). Essa talvez fosse a situação relatada por vários historiadores a respeito das colônias alemãs, homogêneas e isoladas, que permitiram a "formação de uma sociedade étnica, cultural e economicamente diferente da sociedade brasileira" (SEYFERT, G. A conflituosa história da formação da etnicidade teuto-brasileira. In: FIORI, Neide Almeida (Org.). Etnia e educação: a escola "alemã" do Brasil e estudos congêneres. Florianópolis: Ed. da UFSC; Tubarão: Editora Unisul, 2003, p. 28), como ocorreu em várias regiões do Rio Grande do Sul e Santa Catarina.

29 A esse respeito: "Há que convir, com [Fredrik] Barth, que a etnicidade é uma forma de organização social, baseada na atribuição categorial que classifica as pessoas em função de sua origem suposta, que se acha validada na interação social pela ativação de signos culturais socialmente diferenciadores" (POUTIGNAT, P.; STREIFF-FENART, J. Teorias da etnicidade: seguido de grupos étnicos e suas fronteiras, de Fredrik Barth. São Paulo: Fundação Editora da UNESP, 1998, p. 141). "A pertença étnica não pode ser determinada senão em relação a uma linha de demarcação entre os membros e os não-membros. Para que a noção de grupo étnico tenha um sentido, é preciso que os atores possam se dar conta das fronteiras (grifo nosso) que marcam o sistema social ao qual acham que pertencem e para além dos quais eles identificam outros atores implicados em um outro sistema social" (Ibid., p. 152). 
vontade de demarcar limites entre "eles" e "nós", estabelecendo e mantendo fronteiras. Apesar de mencionar algumas vezes dificuldades relacionadas ao idioma, em nenhum momento Gustav Hermann queixou-se explicitamente de qualquer discriminação por ser "alemão" ou evangélico e luterano. Entretanto, o episódio do cemitério era revelador de uma relativa marginalidade que poderia emergir num futuro próximo, pois o catolicismo era religião oficial do Império brasileiro ${ }^{30}$. Por conseguinte, embora a distinção "nós versus outro" pudesse ser até significativa em alguns momentos, tal fato, ao que tudo indica, era minimizado pela necessidade dos Strobel em vencer as dificuldades desses primeiros tempos e pelas boas relações desenvolvidas pela família na sociedade anfitriã.

Suas memórias, porém, foram escritas num outro contexto, e diversos trechos deixavam transparecer uma atitude crítica reveladora da "construção social da pertença"31.

Quando um não católico procurava tratamento (no Hospital de Caridade) era aceito de má vontade e sujeito a discriminações e restrições diversas, forçando-o a sair do hospital o mais breve possível. Naturalmente este procedimento provocou certa revolta e manifestações de desagrado por parte dos emigrantes $[\mathrm{sic}]^{32}$.

Igualmente, não perdoou o Padre João, que batizou suas irmãs ${ }^{33} \mathrm{e}$, aproveitando para criticar o celibato sacerdotal, escreveu que o Vigário de São José era muito mal educado e que, "aparentemente, não tinha conservado a sua castidade, pois criava um menino que o chamava de "papai". E foi mordaz:

O celibato é uma condição imposta aos religiosos católicos, porém criar filhos era permitido. Nesta época em Curitiba vivia

30 “A Religião Catholica Apostolica Romana continuará a ser a Religião do Imperio. Todas as outras Religiões serão permitidas com seu culto domestico, ou particular em casas para isso destinadas, sem fórma alguma exterior do Templo" (Artigo 5..$^{\circ}$ da Constituição de 1824, disponível em: <http://www. planalto.gov.br/ccivil_03/constituicao/constitui\%C3\%A7ao24htm>). Acesso em: 25 de fevereiro de 2009.

31 POUTIGNAT, P.; STREIFF-FENART, J. Op. cit., 1998, p. 125.

32 STROBEL, G. H. Op. cit., 1987, p. 122-123.

33 "O Padre João batizava estas crianças alemães ( sic) de bom grado, mesmo não tendo grande simpatia pelos alemães” (Ibid., p. 69). 
um padre, que contavam tinha sido pai trinta e três vezes. É de admirar que a cegonha seja tão generosa na distribuição de bebês aos padres. A cegonha brasileira talvez confunda batina com saia e que quem usa batina também tenha o necessário leite materno. Certamente existem muitos religiosos que a contragosto usavam a batina e que ansiavam por uma vida conjugal normal. Estes deveriam tomar a atitude de seu ex-colega. Como o Dr. Martinho Lutero $[\ldots]^{34}$.

Ao se iniciar o século XX, o tom do manuscrito de Gustav Hermann, em vários momentos, já parece mostrar que as mencionadas diferenças culturais entre os imigrantes (e filhos de imigrantes) e a sociedade anfitriã estavam sendo socialmente organizadas ${ }^{35}$. Seus escritos dirigiam-se agora aos seus descendentes em nome de uma comunidade étnica, cuja identidade era também caracterizada pela confissão religiosa comum e por uma memória coletiva que refletia o relativo isolamento dos luteranos no seio da comunidade anfitriã, majoritariamente católica ${ }^{36}$. Era uma resposta aos "outros" que acusavam a igreja evangélica de antibrasileira, "principalmente nos períodos de crise e sempre que surgiam as especulações sobre o 'perigo alemão', sofrendo, nessas ocasiões, críticas violentas por parte da imprensa e das autoridades luso-brasileiras" ${ }^{37}$.

Essa atitude da testemunha seria fruto das mudanças das situações de contato que começaram a se evidenciar anos antes, a partir do desenho de um novo e promissor mercado de trabalho para Christian August e seus filhos. Este se traduzia em demandas de obras públicas exigidas pela nova Província e dos imigrantes de origem alemã que, cada vez mais, requisitavam seus serviços especializados numa técnica que era familiar a eles ${ }^{38}$. Porém, continuavam a morar relativamente distantes dos imigrantes germânicos que se radicavam na cidade, organizando suas chácaras ao norte da capital.

34 Ibid., p. 69-70.

35 CUCHE, D. A noção de cultura nas ciências sociais. 2. ed. Bauru: EDUSC, 2002, p. 201.

36 PRIEN, 2001, p. 90-93; HOBSBAWM, E. J. A era dos impérios: 1875-1914. 9. ed. Rio de Janeiro: Paz e Terra, 2005, p. 218-219.

37 SEYFERT, G. Nacionalismo e identidade ética. A ideologia germanista e o grupo étnico teuto-brasileiro numa comunidade do Vale do Itajaí. Florianópolis: Fundação Catarinense de Cultura, 1981, p. 144.

38 MACHADO, C. S. Op. cit., 1998, p. 34. 
Iríamos encontrá-los, pois, em Campo Largo, e lá devem ter permanecido ainda alguns anos ${ }^{39}$; entretanto, por volta de 1860 , já moravam em casa própria, exteriorizando uma ascensão evidente que os levou "a um padrão de vida relativamente bom e decente":

Um vizinho nosso, Bernardo da Cruz, propôs ao nosso pai a venda de uma sua propriedade localizada entre São José e a Costeira, constituída por um terreno com uma boa casa, terreno cercado para plantação e com um tanque com monjolo. Meus pais poderiam pagar em parcelas e parte do preço seria pago pelo trabalho na construção de uma casa para Bernardo pelo meu pai. O negócio foi acertado e em pouco tempo mudamos para nossa primeira casa própria ${ }^{40}$.

O relato de Gustav Hermann é pouco preciso ao contar o tempo, o que dificulta a construção de uma cronologia para a história da sua família. De qualquer forma, percebemos que os Strobel progrediram consideravelmente nesses anos e é nesse âmbito - e do crescimento material - que parece se desenrolar um processo de aproximação mais efetiva da família com o que se conformava gradativamente como um "grupo" de origem germânica. Essa aproximação, de início, parece ter sido de natureza muito mais profissional. Todos os filhos, como menciono adiante, casaram-se com pessoas de origem alemã, a maioria imigrantes; entretanto, como mostra Cacilda Machado, havia vínculos de interesse entre as famílias dos noivos:

Ferdinand Wendt (pedreiro), Christiano Osternack (oleiro) e Sebastian Weckerlin (carpinteiro) exercem, todos eles, profissões do ramo da construção civil, tal como Christian, Gustav e Emil Strobel. Assim, se religião e, principalmente, etnia comuns aparecem como pré-requisitos para a escolha do cônjuge, foi através dos vínculos profissionais que estes princípios básicos puderam ser viabilizados ${ }^{41}$.

39 Os escritos de Gustav não mencionam a possível mudança posterior da família para uma região mais central da cidade. Simplesmente informam que, ao se casar em 1875, construiu sua própria casa "junto ao hospital" (de caridade), em região relativamente central de Curitiba (STROBEL, G. H. Op. cit., 1987, p. 126).

40 STROBEL, G. H. Op. cit., 1987, p. 64.

41 MACHADO, C. S. Op. cit., 1998, p. 49. 
Desenvolviam-se assim uma "comunicação cultural" e uma sociabilidade entre os imigrantes e seus descendentes que permitia gradativamente o estabelecimento de fronteiras "por meio de símbolos simultaneamente compreensíveis pelos insiders e pelos outsiders" ${ }^{42}$ : por exemplo, a Muttersprache (a língua-mãe) e a confissão evangélica.

Por outro lado, é sintomático de certo isolamento que Christian, a mulher e os filhos não estivessem relacionados na lista fundadora da Deutsche Evangelische Gemeinde em 1866, constituída por 11 associados domiciliados em Morretes, no litoral da Província, e por 54 que moravam na capital ${ }^{43}$, o que revela a complexidade da constituição da etnicidade e da formação dos grupos étnicos.

Com o passar dos anos, o contexto gradativamente se modificava. A partir da década de 1870, os imigrantes - quer os pioneiros, quer os que continuavam a chegar - podiam começar a se sentir mais "alemães" (talvez com exceção dos suíços e dos poucos austríacos), o que seria facilitado pelas notícias referentes à criação do Reich, no contexto de uma vitória da Alemanha (leia-se Prússia) contra a França e, nos anos que se seguem, de propaganda pan-germânica. Essa era uma referência. A outra estaria representada por um convívio - diríamos, cada vez mais - solidário entre os imigrantes e, agora, entre seus filhos. Assim, frequentavam a Igreja, a escola alemã, os estabelecimentos comerciais (padarias, armazéns, moinhos, olarias, ferrarias, madeireiras, etc.), como também conviviam cada vez mais com pessoas que falavam melhor o alemão que o português nas dezenas de "Vereine" 44 que começam a proliferar em Curitiba.

Anos mais tarde, não sabemos exatamente quando, as filhas batizadas católicas fizeram sua profissão de fé evangélica ${ }^{45}$ perante a comunidade dos luteranos em Curitiba. De todos os seis filhos, nenhum se casou fora

42 POUTIGNAT, P.; STREIFF-FENART, J. Op. cit., 1998, p. 124.

43 GEMEINDEVERZEICHNISS (von den) evangelischen Mitglieder in Morretes Prov. Paraná; GEMEINDEVERZEICHNISS der evangelischen Mitglieder in Curityba Provinz Parana; 11/11/1866.

44 HOBSBAWM, E. J. Op. cit., 2004, p. 278. Marcando esse típico associativismo, em menos de setenta anos (1856 a 1826), cerca de meia centena de entidades alemãs foram criadas pela comunidade, marcando, direta ou indiretamente, a vida social, econômica, cultural e mesmo política da cidade (NADALIN, 1972, p. 4-5). Ver também, a esse respeito, SEYFERT, G. In: Etnia e educação..., 2003, p. 29, 33.

45 "Anos mais tarde as três meninas foram confirmadas pelo Pastor August Böcker pelo rito evangélico". STROBEL, G. H. Op. cit., 1987, p. 69. Pesquisando os registros da Comunidade Evangélica Luterana de Curitiba, só consegui recuperar a informação referente a Anna (Anna Luiza) Strobel, confirmada em 29 de março de 1874 (Batismos N. ${ }^{\circ}$ 1, 1864-1877). 
da igreja evangélica ou, mesmo, com um filho ou filha dos antigos amigos e vizinhos brasileiros ${ }^{46}$. Sem dúvida, os Strobel estavam integrados à vida social curitibana, mas cada vez mais mantendo relações estreitas com os outros alemães. Que, aliás, continuavam a chegar, de forma contínua: “entre 1850 e 1938 não houve interrupção do fluxo, entrando no país entre 1 e 2 mil alemães por ano (numa estimativa aproximada)"47.

Tudo se passava como, ao amadurecer a segunda geração de "imigrantes", a situação de contato modificava-se de acordo com uma aplicação sui generis da "Lei de Hansen" Christian e Christine que as relações que se estabeleceram no grupo e, com os "outros", começavam a colocar em causa certas fronteiras, mesmo porque os "outros" também começavam a sentir de maneira diferente a novidade dos agrupamentos imigrantes, sobretudo protestantes, na organização social do país ${ }^{49}$. Os estrangeiros, do ponto de vista religioso, mantiveram-se coesos e as comunidades consolidaram-se com apoio na Constituição (a cujas restrições davam interpretação bastante ampla) "e no cumprimento, pelos pastores" - e excepcionalmente por leigos, como no início da vida comunitária em Curitiba - "de agendas reservadas ao sistema religioso e, até então, monopólio católico romano". Batizavam, casavam e sepultavam. Seus filhos estudavam na escola anexa à Igreja sob a direção do Pastor. "Marcaram o cenário onde estivessem, e é claro que a população católica romana, mesmo sem contato litúrgico, não podia fugir a essa intrusão" ${ }^{50}$.

O que se está querendo dizer - para além do que a historiografia enfatiza sobre a contribuição dos imigrantes e descendentes para a urbanização da capital da Província e do respeito que muitos brasileiros tinham pelos estrangeiros -, é que esses também começavam a causar certo mal-estar entre seus anfitriões. $O$ próprio desenvolvimento da cidade traduzia-se em mudanças no seu panorama, com seu cemitério, seu templo, a casa pastoral, a escola, os estabelecimentos comerciais e fabris... Enfim, sua presença

46 MACHADO, C. S. Op. cit., 1998, p. 44.

47 SEYFERT, G. In: Etnia e educação..., 2003, p. 3 (ver capítulo 1, em especial tableau 1 et graphique 2).

48 "Daquilo que o filho quer esquecer, o neto quer lembrar" (POUTIGNAT, P.; STREIFFFENART, J. Op. cit., 1998, p. 71).

49 RIBEIRO, B. Protestantismo no Brasil monárquico, 1822-1888: aspectos culturais de aceitação do protestantismo no Brasil. São Paulo: Pioneira, 1973, p. 81, 91.

50 Ibid., p. 85. 
econômica, física e espiritual ${ }^{51}$. Bigg-Wither, ao voltar à cidade em outubro de 1873 , anotou que "o elemento alemão parecia ter aumentado muito no lugar" e admirou-se de gigantesco edifício que estava em construção, "mais no moderno estilo de um hotel de Londres do que de qualquer dos que vira no Rio e, em todos os lados, havia sinais inequívocos de progresso" ${ }^{2}$. Ou seja, mudanças que caminhavam pari passu com o endurecimento das representações sociais e das tensões urbanas. Assim, por exemplo, se as autoridades eram coniventes e as leis do país toleravam a religião protestante, "já não a toleravam muito dos padres, bem como a população por eles influenciada" ${ }^{53}$. De maneira mais ampla, Giralda Seyfert assinala que, coincidentemente com a chegada de representantes étnicos da comunidade de fala alemã no Sul do Brasil no Congresso Nacional e nas assembleias provinciais, no final do oitocentos, delineia-se o verdadeiro clima de conflito, acirrado pelo incômodo que começava a se tornar a cada vez mais atuante imprensa teuto-brasileira. Parcela da opinião pública brasileira acreditava que estes e outros sinais (incentivo à imigração alemã e a propaganda pangermanista) indicavam interesses expansionistas do Império Alemão na regiã $0^{54}$, principalmente a partir dos anos $1890^{55}$.

É nessa conjuntura que vem se esboçando que encontramos traços da presença de Gustav Hermann - ele, que havia crescido entre os "caboclos" e que havia aprendido a profissão de carpinteiro com seu pai - como associado fundador da sociedade dos artífices alemães em Curitiba (Handwerker Unterstützungs Verein). Seu irmão Robert Emil, também carpinteiro, pelo que parece era mais ativo: foi vice-presidente na primeira diretoria dessa Associação, quando da sua fundação em 19 de julho de $1884^{56}$, e várias vezes membro da diretoria (Vorsteher) do Deutscher Sängerbund, em 1890, 1891,1895 e $1903^{57}$.

51 Ibid., p. 91.

52 BIGG-WITHER, T. P. Novo caminho no Brasil meridional: a Província do Paraná. Três anos em suas florestas e campos: 1872-1875. Rio de Janeiro: J.Olympio/Curitiba: Universidade Federal do Paraná, 1974, p. 323.

53 RIBEIRO, B. Op. cit., 1973, p. 101.

54 SEYFERT, G. In: Etnia e educação..., 2003, p. 42.

55 MAGALHÃES, M. B. D. Pangermanismo e nazismo: a trajetória alemã rumo ao Brasil. Campinas: Editora da UNICAMP/FAPESP, 1998, p. 103-105.

5650 JAHRE Handwerker, 1934, p. 25.

57 O Deuscher Saengerbund (Associação de Cantores Alemães) resultou da fusão, em 4 de junho de 1884, do Gesangverein Germânia (1869) e do Gesangverein Concordia (1873). Dificilmente deixam de ser 
Gustav Hermann aprendera naturalmente o alemão na sua casa e o português no relacionamento com os vizinhos e com os clientes. Entretanto, nunca fora à escola:

Gastos com estudos meu pai não teve comigo, pois em todo Paraná não havia uma única escola alemã ${ }^{58}$, e como eu cresci entre os caboclos nas cercanias de São José, na minha juventude não cursei escola alguma, pois ao redor também não havia uma única escola brasileira. Minha mãe ensinou-me alguma coisa. Aprendi com ela a ler e escrever em alemão, e mais tarde adquiri alguns livros; com eles, nas horas vagas, à noite e aos domingos fui me instruindo por conta própria. Não me tornei um sábio, mas aprendi o suficiente para o meu ofício e negócios, e fiz progressos em minha vida ${ }^{59}$.

Pelo menos onde o contato com a sociedade anfitriã era mais intenso, como nas cidades, o bilinguismo era característica dos descendentes dos imigrantes, mas não há dúvidas de que, principalmente na intimidade do seu Heim (lar), tinham tendência em se expressar em alemão ${ }^{60}$, o que era fortalecido pela convivência na comunidade, pela leitura de jornais, por revistas e livros recebidos da Alemanha, pelos almanaques com finalidades diversas que proliferavam no Sul, pelas viagens que faziam... Gustav foi à antiga Colônia $\mathrm{D}$. Francisca pelo menos duas vezes ${ }^{61}$, embora se possa acreditar que seus contatos comerciais e de amizade o levassem a relações frequentes com os joinvillenses ${ }^{62} \mathrm{e}$, o que também é provável, com outras

encontradas evidências, onde quer que se localizassem grupos imigrantes alemães, de algo que os lembrasse de um ideal da "Concórdia Alemã", ou Deustche Einigkeit. O mundo dos imigrantes festejou a unificação alemã em 1870 e, em Curitiba, programou para junho de 1871 a Deutsche Einigkets-und-Fridenfest, como testemunha uma foto do acervo do atual Clube Concórdia, em Curitiba (NADALIN, 1972, p. 26).

58 De fato, o primeiro pastor da Deutsche Evangelische Gemeinde foi também o primeiro professor de uma escola alemã, já em 1867. Gustav teria, nesse momento, 16 anos, e, pelo que consta nas suas memórias, já acompanhava seu pai no trabalho.

59 STROBEL, G. H. Op. cit., 1987, p. 94.

60 "Havia nas colônias uma relação entre escola, religião e língua alemã que foi fundamental para a preservação do Deutschtum, fronteira ideológica que marca a etnicidade teuto-brasileira. A estes três elementos se soma um quarto, talvez considerado o mais fundamental, o lar (Heim), reduto íntimo da etnicidade pelo seu papel na preservação da lingua alemã” (SEYFERT, G. In: Etnia e educação..., 2003, p. 33-34).

61 SEYFERT, G. In: Etnia e educação..., 2003, p. 99, 103.

62 MACHADO, C. S. Op. cit., 1998, p. 50-51. 
"colônias". A respeito de uma excursão que realizou ainda adolescente, em 1865, registrou em suas memórias:

Joinville, depois de dez anos que a deixamos, sofreu transformações visíveis para melhor. As ruas limpas, com casas bonitas e grandes. Na zona do porto, onde outrora caçavam-se os temidos jacarés, agora havia diversos estabelecimentos comerciais. [...] Joinville, com quatorze anos de existência, em muitos sentidos já tinha progredido mais que muitos lugarejos existentes há cem anos! [...] podia-se constatar que com o trabalho dos seus moradores de origem alemã o progresso era notável ${ }^{63}$.

Sobre outro passeio, agora junto com sua esposa e na companhia de vários amigos, e bem mais tarde (1901), foi a Joinville para participar dos festejos dos cinquenta anos da cidade.

Tudo tinha mudado. As altas árvores na beira do rio tinham desaparecido, só restando a vegetação baixa, deixando-o mais livre. Em minha memória eu via ainda as altas e ameaçadoras árvores que existiam em 1854. [...] Joinville tinha se transformado em uma cidade modelo, que produzia muitos artefatos ainda inéditos em outras cidades do Brasil ${ }^{64}$.

Como muitos teuto-brasileiros, viajou algumas vezes à Alemanha: "da nossa família, somente meu irmão Roberto e eu voltamos a visitar algumas vezes a nossa cidade natal" ${ }^{\prime 65}$ e, por ocasião da Grande Guerra, ficou retido na Europa. Possuía, portanto, recursos, o que o permitia ligar--se fisicamente a seu país natal: levou para a Alemanha um filho doente, recém-casado, e mandou outro para lá estudar ${ }^{66}$.

63 STROBEL, G. H. Op. cit., 1987, p. 102-103.

64 Ibid., p. 104.

65 Ibid., p. 20.

66 Seu tradutor anota: “Gustav Hermann Strobel realizou algumas viagens à Alemanha, sendo que em uma destas (1913), foi acompanhando seu filho Friedrich Alvin, o qual, acometido por moléstia, foi em busca de tratamento e lá faleceu" (Idem, p. 141). Cacilda Machado, por outro lado, foi informada de que Gustav Hermann pôde [...] "financiar estudos de um de seus filhos naquele país" (MACHADO, C. S. Op. cit., 1998, p. 67). 
A ligação com a Alemanha, portanto, baseia-se na comunidade de sangue e língua, naturalizada através de um modo de vida alemão preservado nas colônias - numa reapropriação da ideologia nacionalista anterior à unificação alemã, que podia falar de uma nação sem Estado. De certa forma isso explica por que associações culturais, de tiro e ginástica, juntamente com a família, a preservação do idioma, a endogamia e até mesmo a nova sociedade (imaginada como produto da capacidade herdada de trabalho, portanto, associada à raça), são concebidos como fronteira étnica a preservar ${ }^{67}$.

Em consequência, via-se, como outros membros do grupo étnico, como "alemão" - falando, escrevendo e pensando em sua língua natal -, embora fosse cidadão brasileiro. Se ele levou seu filho Friedrich Alvin para se tratar na Alemanha, outros enviavam seus filhos "para serem educados no antigo país" ${ }^{\prime 68}$. Isso era verdade na medida em que se acreditavam e se viam dessa forma, membros de uma Volksgemeinschaft (comunidade nacional) que transcendia as fronteiras da cidadania; distinto, pois, da origem "brasileira" de seus concidadãos e agindo, portanto, de modo a validar sua "germanidade" 69 .

Essas ligações é que permitem inferir, finalmente, que Gustav Hermann construía, junto com os que professavam a mesma identidade "alemã" (ou, talvez melhor, teuto-brasileira), limites étnicos que mantinham a certa distância membros da sociedade brasileira e de outros grupos de descendentes de imigrantes que estavam se constituindo em volta de Curitiba. Revelador nesse sentido é o que comenta, ao rememorar a profusão de caça que havia na região:

Até a vinda dos imigrantes italianos todos os anos tinha caça em quantidade, pois nós (grifo nosso) respeitávamos a época de

67 SEYFERT, 1993, p. 5. É preciso ainda “observar que o termo 'colônia', nesse contexto, não diz respeito apenas ao meio rural ou às legiões de assentamentos de imigrantes alemães, mas também às comunidades (no sentido de comunidades étnicas) que congregam pessoas dessa origem nas cidades maiores, como Porto Alegre, Curitiba ou São Paulo" (Ibid.,, 1994, p. 190). Pessoalmente, eu tenho lembrança de vários descendentes de alemães em Curitiba que, ao se referirem a outros de mesma origem, qualificam-nos como sendo "da colônia".

68 HOBSBAWM, E. J. Op. cit., 2004, p. 278.

69 A partir das informações propiciadas por SEYFERT (1993, p. 5), inspiramo-nos em Moermann, 1965, apud Poutignat, 84: "Alguém é um lue pelo fato de se crer e denominar-se lue e agir de modo a validar sua lue-tude". 
reprodução suspendendo a caça. Mas com a vinda dos italianos, a caça começou a declinar, pois estes não respeitavam a época da reprodução caçando o ano todo e toda espécie de aves" ${ }^{\text {"70 }}$.

Por volta da passagem do século - como mencionei -, já se avolumavam as críticas ao que se afirmava como resistência à "assimilação" manifestada pelos imigrantes de origem germânica e seus descendentes. Tal resistência, agravada pela "maior visibilidade política das antigas colônias e seu crescimento econômico por um lado, e a formulação de uma ideologia étnica que reivindicava o direito à especificidade cultural e mesmo à endogamia por outro" "71, chocava-se com a ideologia do branqueamento manifestada por parte das elites brasileiras. No início do novecentos, Gustav Hermann fornecia a sua versão do problema:

Nos primeiros anos da chegada dos imigrantes alemães a Curitiba, os brasileiros admiraram a tenacidade no trabalho e os novos conhecimentos que foram introduzidos nas diversas atividades por eles exercidas. Mas, com o passar dos anos, quando os imigrantes começaram a progredir, aos poucos adquirindo propriedades, elevando o padrão de vida, como também possuindo os direitos de cidadãos brasileiros - e com isso reivindicando o direito de voto - desagradaram certas castas de nativos daqui da terra ${ }^{72}$.

Em alguns momentos, seu relato coloca em relevo a tenacidade da família em sobreviver. Mais ainda, salienta o trabalho realizado, o trabalho típico de um "alemão", distinção que logo começou a incorporar o discurso étnico, pois nas histórias das trajetórias bem-sucedidas dos imigrantes "o ponto de partida é quase sempre o colono na selva, o pioneiro!"73 Não foi uma vertente do que aconteceu com Christian e sua família?

Comentava ainda nosso memorialista que as mencionadas "castas" achavam que "a direção da política e condução dos negócios da nação seria

71 SEYFERT, 1993, p. 3.

72 STROBEL, G. H. Op. cit., 1987, p. 135.

73 SEYFERT, 1993, p. 4 
de exclusiva competência dos 'donos do Brasil"' "74. Na opinião de Gustav, os verdadeiros "donos da terra" seriam os índios, "pois todos os outros são imigrantes que chegaram ao novo mundo a partir do ano de 1500 " 75 . Assim poder-se-iam justificar as duas esferas de atuação, a comunidade étnica e o Estado brasileiro: "uma pequena pátria alemã no Brasil [...] construída pelo esforço coletivo dos pioneiros, e a pátria brasileira, que remete à cidadania referenciada pelo direito de solo" $"$.

Gustav Hermann manifestava-se, igualmente, contra os jornais que publicavam artigos "atacando gratuitamente os alemães. Os redatores e responsáveis não deveriam dar guarda a estas provocações, pois essas atitudes só provocam animosidades" $" 77$.

Quando um repórter inglês ou francês irresponsável resolve escrever sobre o chamado "Perigo alemão no Brasil", esse assunto é comumente matéria para ser transcrita por diversos periódicos no Brasil. E se não fossem prontamente rebatidos por articulistas nacionais, de espírito arejado e bom senso, certamente pelos seus autores, que obviamente é envenenar e indispor os imigrantes alemães com os nacionais [sic]. A ralé certamente aproveitaria a menor oportunidade para saquear e destruir os estabelecimentos e propriedades destes alemães. Estas pessoas que se dispuseram a defender os nossos patrícios não devem ser esquecidas por nós. Entre elas devo citar o senhor Alcides Munhoz $^{78}$. Por outro lado também os jacobinos (que pregam o ódio aos estrangeiros) procuraram acirrar os ânimos contra os alemães e descendentes de outras nacionalidades; esses não devem ser olvidados para na hora de eleições, se fazer justiça aos que defendem os que trabalham pelo progresso desta terra ${ }^{79}$.

74 STROBEL, G. H. Op. cit., 1987, p. 137.

75 Id.

76 SEYFERT, 1993, p. 5.

77 STROBEL, G. H. Op. cit., 1987, p. 137.

78 Certamente Gustav Hermann Strobel refere-se à brochura publicada em 1907 por Alcides Munhoz intitulada "O Sr. Sylvio Romero e o Allemanismo no Sul do Brasil: o Paraná". Sylvio Romero ataca no seu livro $O$ allemanismo no Sul do Brasil: seus perigos e meios de os conjurar (Rio de Janeiro: Heitor Ribeiro, 1906) o expansionismo colonialista dos alemães, referindo-se diretamente ao perigo das colônias alemãs no Sul (Rio Grande do Sul, Santa Catarina e Paraná).

79 STROBEL, G. H. Op. cit., 1987, p. 138. 
A questão é que, de fato, havia uma retórica racista e expansionista manifestada pela Liga Pangermânica (Alldeutsche Verband) que influenciava com maior ou menor grau muitos jornais teuto-brasileiros, e "a presença étnica das colônias alemãs concentradas no sul, além das denúncias norte-americanas, francesas e inglesas sobre os interesses da Alemanha na América do Sul, serviam às especulações sobre intenções separatistas dos colonos" $"$. Este era o chamado "perigo alemão", clamor que se tonificaria no período entre as duas Guerras Mundiais.

A presença de imigrantes na capital da Província desenvolvendo distintas subculturas étnicas trouxe, notadamente, um novo colorido à cidade. Grupos de estrangeiros, tais como "alemães", "italianos", "poloneses" ou "ucranianos", que tinham como referência sua aldeia natal e adquiriam consciência de si pela imposição - às vezes de caráter xenófoba - dos "outros", desenvolveram suas individualidades a partir de algumas restrições.

Referimo-nos, por exemplo, às exigências institucionais comuns em relação à assimilação: na segunda metade do século XIX, adentrando mesmo no século seguinte, "a humanidade foi dividida segundo a 'raça', ideia que penetrou na ideologia do período quase tão profundamente como a de "progresso" "81. Aliás, muitas vezes essas duas noções eram indissociáveis: no Brasil, em especial, acreditava-se que o progresso do país dependia da "arianização", "ou seja, do 'branqueamento' progressivo do povo através de casamento inter-racial" "82. Endogamia étnica e a consideração de uma religião herética estavam, da mesma forma, interligadas, contribuindo, segundo se pensava, para a "inassimilação" do imigrante alemão e seus descendentes. $\mathrm{O}$ que se pretendia impor aos estrangeiros, finalmente, não era coerente para indivíduos que possuíam o "poderoso incentivo da nostalgia" ${ }^{83}$ e que podiam "vangloriar-se de uma herança cultural comum"

É dessa forma que se solidificava uma nova identidade nos imigrantes de origem germânica e seus descendentes - fundada, sem dúvida,

80 SEYFERT, G., 1993, p. 6. "Nos Estados Unidos surgiram diversas publicações, de caráter alarmista, denunciando os interesses pangermânicos no Sul do Brasil - região que passou a ser chamada de 'Little Germany' numa alusão às possíveis tentativas futuras de transformá-la numa verdadeira colônia alemã. As 'colônias alemãs' ganharam, assim, uma notoriedade internacional, em função do jogo de interesses imperialistas de norte-americanos, alemães, ingleses e franceses" (Ibid., 2003, p. 49).

81 HOBSBAWM, E. J. A era dos impérios..., 2005, p. 54.

82 Id.

83 Ibid., p. 208.

84 POUTIGNAT; STREIFF-FENART, 1998, p. 79. 
em "traços culturais diferenciadores" ${ }^{85}$ que, independente de já existirem quando dos primeiros contatos, tomavam forma no curso de uma história comum que se iniciava provavelmente na segunda geração do grupo. Era transmitida de maneira seletiva por uma memória coletiva que também interpretava essa história e essa origem comum: não eram mais pomeranos, prussianos, hannoverianos, hamburgueses, renanos; não eram mais nativos do Schleswig, do Holstein, da Turíngia, da Saxônia, do Brandenburgo; não eram mais ricos ou pobres, patrões ou empregados, camponeses ou citadinos e, mesmo, não eram mais católicos ou protestantes: eram alemães, "unidos por um passado pioneiro comum que, simbolicamente, representa a identidade étnica"86; eram alemães, reunidos em torno de símbolos identitários, como a Muttersprache ${ }^{87}$ - preservada no lar (Heim), "reduto íntimo da etnicidade" $" 88$, o "trabalho alemão" $" 89$ e, geralmente, a Igreja Luterana ${ }^{90}$. Eram, finalmente, "alemães" - acrescentando uma pitada de complexidade à questão -, aos quais se agregavam outros imigrantes que continuavam a chegar, agora com passaporte fornecido pelo Reich constituído em 1870.

Embora sempre seja difícil generalizar a partir de um caso, o texto de Gustav Hermann Strobel deu o que pensar, corroborando a análise de que os imigrantes alemães e seus descendentes em Curitiba formavam, um grupo étnico que se constitui como tal a partir de contrastes culturais evidenciados desde o início da presença dos estrangeiros na cidade. Como outros imigrantes (e descendentes), nosso memorialista, vivendo desde criança no Brasil e em contato direto com a sociedade que o albergou, foi educado e alfabetizado na língua dos seus antepassados, vivenciando e pugnando pela cultura ancestral - evidentemente aprendendo e se comu-

85 LAPIERRE, J-W. Prefácio. In: POUTIGNAT, P.; STREIFF-FENART, J. Teorias da etnicidade. São Paulo: Fundação Editora da UNESP, 1998, p. 12.

86 SEYFERT, G. A identidade teuto-brasileira numa perspectiva histórica. In: MAUCH, C.; VASCONCELLOS, N. Os alemães no Sul do Brasil: cultura, etnicidade, história. Canoas: Ed. ULBRA, 1994 , p. 25.

87 Mesmo que não se saiba exatamente o que é esta língua comum. Gustav Hermann Strobel, ao relatar as conversas no rancho habitado pelos trabalhadores da Estrada da Graciosa, em grande parte imigrantes de origem "germânica", menciona uma discussão entre eles: "Certa vez discutia-se em que zona se falava mais corretamente a língua alemã e um suíço disse que eram os suíços, o que provocou gargalhadas entre os presentes" (STROBEL, G. H. Op. cit., 1987, p 111).

88 SEYFERT, G. In: Etnia e educação..., 2003, p. 34.

89 Ibid., p. 4.

90 “A consciência étnica alemã, a língua alemã e a igreja luterana [...] são inseparáveis, e Lutero é sempre apresentado como o primeiro dos nacionalistas alemães” (SEYFERT, G. Op. cit., 1981, p. 142). 
nicando também portugués. Ao se recordar de um ambiente de necessária integração, mostrava-se condescendente ao tratar dos diversos aspectos que caracterizavam a sociedade local, mormente o escravismo e, em especial, a presença dos "caboclos". Quase como contraponto, procura salientar e dignificar o valor do trabalho, principalmente alemão ${ }^{91}$, não necessariamente para o enriquecimento, mas para permitir ao sujeito uma vida relativamente boa e decente. Entretanto, parece nesse ponto comungar com a ideia característica da "teuto-brasilianidade" de que o "trabalho alemão" era e foi veículo de progresso - principalmente visualizando, no horizonte, uma "pátria" brasileira e sua história. Finalmente, seus escritos revelam um homem viajado, o que permitiu manter contatos relativamente frequentes com as comunidades de teuto-brasileiros e, o que também é sintomático, com os descendentes dos alemães que não emigraram.

Assim, como procurei deixar claro, não estou sozinho ao estabelecer a hipótese de que a etnicidade manifesta-se a partir de um segundo momento de contatos, provavelmente quando assume na Capital uma "segunda geração" de teuto-brasileiros (e aqui eu incluiria, ainda provisoriamente, parcela de migrantes que continuam a chegar em fluxos contínuos). É dessa maneira que a experiência curitibana agregar-se-ia à das diversas comunidades "coloniais" instaladas no Brasil na edificação de uma ideologia étnica teuto-brasileira (Deutschbrasilianertum): a etnicidade constrói-se a partir de cada experiência individual associada aos contatos culturais não só de natureza interétnica, mas, de modo igual, relacionados à troca de experiências desenvolvidas com os contatos que as diversas comunidades mantinham entre si.

$\mathrm{O}$ que eu estou querendo naturalmente lembrar, como Michael Banton, é a ideia da articulação de duas fronteiras: de um lado, uma "fronteira de exclusão, que reflete o modo como a seção mais poderosa da população define uma categoria social menos poderosa como um grupo que deve ser posto de lado"; de outro, os membros da minoria étnica distintos em diversas comunidades espalhadas principalmente no Brasil Meridional que se reconheciam dessa forma e incluíam-se numa "fronteira de inclusão, refletindo o reconhecimento que os membros da minoria têm uns dos

91 Nunca é demais repetir, como Seyfert, o "caráter estigmatizante" associado até hoje pelos descendentes de alemães à categoria caboclo e subjacente à ideia da superioridade do "trabalho alemão" (Ibid., p. 60). 
outros como pertencentes a uma unidade" ${ }^{92}$. Esse reconhecimento de que pertenciam a uma mesma "colônia", congregando várias "colônias" constituindo situações de aculturação distintas - e as consequentes interações -, provinha não só das migrações internas e dos contatos resultantes; procedia, principalmente, da migração de ideias geradas pelo produto intelectual da inteligentsia teuto-brasileira, salientando-se conteúdos de certos jornais e de uma literatura original veiculada nos Kalender (almanaques) ${ }^{93}$. Os autores circulavam tanto por meio da leitura propiciada por essas publicações teutobrasileiras quanto pela própria movimentação pelas "colônias". Por exemplo, o joinvillense Ernst Niemeyer, filho de um diretor da Colônia, mudou-se para Curitiba, onde deve ter produzido parte de sua numerosa obra, fruto sem dúvida dos contatos que fazia no âmbito da fronteira de inclusão ${ }^{94}$. Giralda Seyfert nota que, entre outros veículos em língua alemã, o jornal Der Kompass (1901-1939), editado na capital paranaense, era vendido, por exemplo, no Vale do Itajaí e lido, igualmente, em outras partes do Sul e em São Paulo ${ }^{95}$. O mesmo jornal, rotulado como expressivo pela autora, tinha simpatia, como outros, por muitas das ideias do Deutschbrasilianertum e, também como outros, fazia críticas às ideias nazistas do Volksgenosse (os teuto-brasileiros não seriam cidadãos brasileiros, mas compatriotas dos alemães); nisso contrapunha-se evidentemente ao Volk und Heimat (Povo e Pátria), editado pelo diretório paulista do NSDAP.

92 BANTON, M. The idea of race. Londres: Tavistock, 1977, p. 147 (apud SEYFERT, 2003, p. 31; sem grifo no original). Observo que as "fronteiras de exclusão" parecem corresponder, de certo modo, às "fronteiras étnicas" conceituadas por Fredrik Barth (1998).

93 SEYFERT, G. Nacionalismo e identidade étnica..., 1981, p. 107-124.

94 "Johann Friedrich Georg Ernest Niemeyer, [...] - autor prolixo e contribuinte obstinado dos Kalender. Significativamente, assinava seus escritos como Ernesto Niemeyer (adotando, portanto, um prenome luso). Nasceu em Joinville em 1863, filho mais velho do diretor daquela colônia, o engenheiro Louis Niemeyer. Mais tarde mudou-se para Curitiba, cidade para onde se dirigiram muitos imigrantes inicialmente localizados em Joinville. Tornou-se funcionário público federal, tendo ocupado o cargo de chefe do serviço telegráfico. Sua obra é bastante variada: publicou romances e novelas, escreveu inúmeras crônicas para jornais e almanaques e destacou-se como poeta. Suas poesias foram publicadas, inicialmente, na imprensa teuto-brasileira, sendo posteriormente agrupadas em dois volumes com o título Eines Brasilianers Lied (o primeiro publicado em Porto Alegre, em 1897, e o segundo em Berlim, em 1910)" (SEYFERT, G. A idéia de cultura teuto-brasileira: literatura, identidade e os significados da etnicidade. Horizontes Antropológicos. Porto Alegre, v. 10, n. 22, p. 160, jul./dez. 2004). No início da década de 1970, utilizei como fonte a pequena brochura que produziu a respeito do Clube Concórdia (NIEMEYER, E. 50 Jahre Verein Deutscher Sängerbund. Curitiba: Ed. Niemeyer/Tip. João Haupt \& Cia., 1934). O mesmo autor, de acordo com Wilson Martins, também escreveu um livro destinado aos alemães que gostariam de emigrar para o Brasil (1989, p. 123, 451) intitulado Die Deutschen in Brasilien (Curitiba: Impressora Paranaense, 1926). 95 SEYFERT, G. A. In: Etnia e educação..., 2003, p. 40-41. 
A mesma autora, focando suas pesquisas numa historiografia e em pesquisas construídas em análises de agrupamentos caracteristicamente coloniais, assegura que "os teuto-brasileiros começaram a agir como grupo étnico quando se rompeu o isolamento das áreas coloniais, no final do século XIX" ${ }^{\prime 96}$. Mais do que uma resposta demandada por essas comunidades, eu diria que as "escolas alemãs e suas entidades de apoio, as associações de caráter beneficente e assistencial, a organização inicial da assistência religiosa (tanto católica como luterana) na forma comunitária, as associações culturais e recreativas (como as sociedades de canto, de tiro, de ginástica etc.)" ${ }^{97}$ podiam replicar não só o isolamento geográfico mas, sobretudo, o cultural. Respondiam à diferenciação generalizada entre o "nós" irmanados pelo Deutschbrasilianertum (fronteiras de inclusão) e os "outros" (fronteiras de exclusão) que se colocava onde quer que houvesse imigrantes e descendentes, tanto nos núcleos coloniais como nas "colônias" instaladas no âmbito dos centros urbanos, como Curitiba. Tanto é verdade que não só a Igreja luterana desenvolveu-se na cidade, mas igualmente a escola alemã e, como mencionei, dezenas de Vereine com múltiplas e variadas finalidades (beneficência, canto coral, música, leitura, ginástica e esportes, teatro, divertimentos, veteranos de guerra, jardinagem, bombeiros voluntários etc. $)^{98}$.

No âmbito dessas fronteiras de inclusão desenvolveu-se uma identidade étnica, ou como talvez convenha melhor ao historiador, identidades étnicas, que não constituem conjuntos intemporais, imutáveis, de traços culturais e transmitidos de uma geração a outra em cada local onde floresceu uma colônia de "alemães". Em especial no período que nos interessa, localizado mais ou menos na segunda metade do século XIX, ações e reações foram provocadas na fricção entre o "nós", incluídos na inclusão, e os "outros", na exclusão, em sociedades diversas que não cessavam de se transformar. No caso em evidência, uma sociedade urbana ${ }^{99}$.

96 SEYFERT, G. A. In: Etnia e educação..., 2003, p. 60.

97 Ibid., p. 28-29.

98 Ver análise a respeito em NADALIN, 1972, p. 4-7.

99 LAPIERRE, in: Teorias da etnicidade..., 1998, p. 11. Ou, como escreve Jean-Claude RuanoBorbalan, "L'identité n'est plus considérée para les chercheurs comme une substance, un attribut immuable de l'individu ou des collectivités. Tous rappellent, avec insistance, que l'image et l'estime de soi, les identités communautaires ou politiques s'élaborent, se construisent et s'actuallisent sans cesse dans les interactions entre les individus, les groupes et leurs idéologies. [...] Pour les immigrés, la construction identitaire est une dynamique incessante de confrontation aux valeurs dominantes de la societé d'installation et d'affirmation de leur proprie valeur individuelle" (RUANO-BORBALAN, 2004, p. 1-2, 5, respectivamente). 
Assim, se o exemplo da linhagem fundada por Christian e Christine for generalizável, tudo se passa como se, em algumas gerações, os descendentes dos pioneiros fossem continuamente substituídos por membros no$\operatorname{vos}^{100}$. Ou seja, o "nós" associava sucessivamente novos membros oriundos do estrangeiro e de outras regiões do Brasil, mormente de Santa Catarina e Rio Grande do Sul; agregava, de modo igual, pessoas em função de fatores diversos, tais como o casamento com outsiders que se incorporam ao grupo. De maneira inversa, perdia - ou "excluía" - indivíduos pelos mesmos ou outros motivos, indivíduos que "atravessavam" as fronteiras étnicas. Os "outros", é evidente, também constituem uma abstração: no tempo, muda o seu caráter, como mudam os contextos das relações interétnicas.

Com efeito, a identidade étnica, como qualquer identidade, resulta de uma construção social e, por isso mesmo, faz parte da complexidade concernente. Dessa forma, como Dennys Cuche, reafirmamos que as identidades culturais não podem se reduzir a definições simples e "puras". Fazer isso seria desconsiderar a heterogeneidade da sociedade curitibana, em cuja história se movimentam nossos atores.

Nenhum grupo, nenhum indivíduo está fechado a priori em uma identidade unidimensional. $\mathrm{O}$ caráter flutuante que se presta a diversas interpretações ou manipulações é característico da identidade. É isto que dificulta a definição desta identidade ${ }^{101}$.

É, por, por conseguinte, numa situação efervescente do processo de urbanização que esses contatos são otimizados, principalmente se, como vimos com Gustav Hermann Strobel, no âmbito desse processo verifica-se a ascensão social e econômica dos sujeitos. De qualquer forma, "a etnicidade não se manifesta nas condições de isolamento; é, ao contrário, a intensificação das interações características do mundo moderno e do universo urbano que torna salientes as identidades étnicas" ${ }^{102}$. Interações que envolvem insiders e outsiders, como enfatizamos. Interações consequentes aos movimentos internos nas "áreas" de inclusão. Para melhor compreensão dessas

100 Como fonte, dispomos de uma genealogia construída por Egon Strobel, um dos descendentes de Christian August.

101 CUCHE, D. Op. cit., 2002, p. 192.

102 POUTIGNAT, P.; STREIFF-FENART, J. Op. cit., 1998, p. 124. 
questões, urge produzirmos pesquisas comparativas, no sentido de cotejar analiticamente comunidades diversas que se encontram - perdoem-me o neologismo - em áreas de inclusão.

\section{Referências}

BARTH, F. Grupos étnicos e suas fronteiras. In: POUTIGNAT, P.; STREIFFFENART, J. Teorias da etnicidade. São Paulo: Fundação Editora da UNESP, 1998.

BIGG-WITHER, T. P. Novo caminho no Brasil meridional: a Província do Paraná. Três anos em suas florestas e campos; 1872-1875. Rio de Janeiro: J. Olympio/ Curitiba: Universidade Federal do Paraná, 1974.

BÖBEL, M. T.; THIAGO, R. S. Joinville - os pioneiros: depoimentos e história. v. 1, 1851-1866. Joinville: Univille, 2001.

COLATUSSO, D. E. Imigrantes alemães na hierarquia de status da sociedade luso-brasileira (Curitiba, 1869 a 1889). Dissertação (Mestrado) - Universidade Federal do Paraná. Curitiba-PR, 2004. 102p. e anexos. (Texto integral disponível em: $<$ http://www.poshistoria.ufpr.br/bancoteses.htm>).

CUCHE, D. A noção de cultura nas ciências sociais. 2. ed. Bauru: EDUSC, 2002. HOBSBAWM, E. J. A era do capital: 1848-1875. 10. ed. Rio de Janeiro: Paz e Terra, 2004.

. A era dos impérios: 1875-1914. 9. ed. Rio de Janeiro: Paz e Terra, 2005.

LAPIERRE, J.-W. Prefácio. In: POUTIGNAT, P.; STREIFF-FENART, J. Teorias da etnicidade. São Paulo: Fundação Editora da UNESP, 1998.

MACHADO, C. S. De uma família imigrante: sociabilidades e laços de parentesco. Curitiba: Aos Quatro Ventos, 1998.

MAGALHÃES, M. B. D. Pangermanismo e nazismo: a trajetória alemã rumo ao Brasil. Campinas: Editora da UNICAMP/FAPESP, 1998.

MARTINS, W. Um Brasil diferente. (Ensaio sobre fenômenos de aculturação no Paraná). 2. ed. São Paulo: T.A. Queiroz, 1989.

MUNHOZ, A. O Sr. Sylvio Romero e o allemanismo no Sul do Brasil: o Paraná. Curitiba: Officinas de Artes Graphicas de Adolpho Guimarães, 1907.

NADALIN, S. O. Clube Concórdia. Curitiba: Clube Concórdia, 1972.

. A população no passado colonial brasileiro: mobilidade versus estabilidade.

Topoi: Revista de História. Rio de Janeiro: Programa de Pós-Graduação em História Social da UFRJ, v. 4, n. 7, jul./dez. 2003. 
NIEMEYER, E. 50 Jahre Verein Deutscher Sängerbund: Curitiba - 1884-1934. Curitiba: E. Niemeyer/Tip. João Haupt \& Cia., 1934.

POUTIGNAT, P.; STREIFF-FENART, J. Teorias da etnicidade: seguido de grupos étnicos e suas fronteiras, de Fredrik Barth. São Paulo: Fundação Editora da UNESP, 1998.

RIBEIRO, B. Protestantismo no Brasil monárquico, 1822-1888: aspectos culturais de aceitação do protestantismo no Brasil. São Paulo: Pioneira, 1973.

RUANO-BORBALAN, Jean-Claude. La construction de l'identité. In: HALPERN, Catherine; RUANO-BORBALAN, Jean-Claude (Coords.). Identité(s): l'individu, le groupe, la société. Auxerre: PUF/Sciences Humaines Éditions, 2004.

SEYFERT, G. A conflituosa história da formação da etnicidade teuto-brasileira. In: FIORI, N. A. (Org.). Etnia e educação: a escola "alemã" do Brasil e estudos congêneres. Florianópolis: Ed. da UFSC; Tubarão: Editora Unisul, 2003.

. A ideia de cultura teuto-brasileira: literatura, identidade e os significados da etnicidade. Horizontes Antropológicos. Porto Alegre, v. 10, n. 22, jul./dez. 2004. . A identidade teuto-brasileira numa perspectiva histórica. In: $\mathrm{MAUCH}, \mathrm{C}$; VASCONCELLOS, N. Os alemães no Sul do Brasil: cultura, etnicidade, história. Canoas: Ed. ULBRA, 1994.

. Identidade étnica, assimilação e cidadania; a imigração alemã e o Estado Brasileiro. In: ENCONTRO ANUAL DA ANPOCS, XVII. Caxambu, MG, 22-25 outubro de 1993. Disponível em: <http://www.anpocs.org.br/portal/publicacoes/ rbcs_00_26/rbcs26_08.htm>. Acesso em: 1. ${ }^{\circ}$ de janeiro de 2007.

. Nacionalismo e identidade étnica. A ideologia germanista e o grupo étnico teuto-brasileiro numa comunidade do Vale do Itajaí. Florianópolis: Fundação Catarinense de Cultura, 1981.

SINGER, P. Desenvolvimento econômico e evolução urbana: análise da evolução econômica de São Paulo, Blumenau, Porto Alegre, Belo Horizonte e Recife. São Paulo: Edit. Nacional: Edit. USP, 1968.

STROBEL, G. H. Relatos de um pioneiro da imigração alemã. Curitiba: IHGEP, 1987.

WACHTEL, N. A aculturação. In: Le GOFF, J.; NORA, P. História: novos problemas. 3. ed. Rio de Janeiro: Francisco Alves, 1988.

WILLEMS, E. A aculturação dos alemães no Brasil. Estudo antropológico dos imigrantes alemães e seus descendentes no Brasil. 2. ed. São Paulo: Cia. Editora Nacional/INL/MEC, 1980. 